\title{
Proteomic Analysis through Adventitious Rooting of Pinus radiata Stem Cuttings with Different Rooting Capabilities
}

\author{
Carolina Álvarez ${ }^{1,2}$, Luis Valledor ${ }^{3,4}$, Patricia Sáez², Manuel Sánchez-Olate², Darcy Ríos² \\ ${ }^{1}$ Centro Tecnológico de la Planta Forestal (CTPF), Instituto Forestal (INFOR), Sede Bío-Bío, Chile \\ ${ }^{2}$ Laboratorio de Cultivo de Tejidos Vegetales, Facultad de Ciencias Forestales y Centro de Biotecnología, Universidad de Concepción, \\ Concepción, Chile \\ ${ }^{3}$ Laboratories of Adaption Biotechnologies, Global Change Research Centre, Academy of Sciences of the Czech Republic, Brno, Czech \\ Republic \\ ${ }^{4}$ Plant Physiology, Epiphysage Research Group, B.O.S. Department, Faculty of Biology, University of Oviedo, Oviedo, Spain \\ Email: *caalvarez@udec.cl
}

How to cite this paper: Álvarez, C., Valledor, L., Sáez, P., Sánchez-Olate, M. and Ríos, D. (2016) Proteomic Analysis through Adventitious Rooting of Pinus radiata Stem Cuttings with Different Rooting Capabilities. American Journal of Plant Sciences, 7, 1888-1904.

http://dx.doi.org/10.4236/ajps.2016.714174

Received: June 16, 2016

Accepted: September 26, 2016

Published: September 29, 2016

Copyright $\odot 2016$ by authors and Scientific Research Publishing Inc. This work is licensed under the Creative Commons Attribution International License (CC BY 4.0).

http://creativecommons.org/licenses/by/4.0/

(c) (i) Open Access

\begin{abstract}
In forest production systems, vegetative propagation of elite clones through adventitious rooting is a common practice. In Chile, adventitious rooting is the main methodology for vegetative reproduction of Pinus radiata. However, the capability of produce adventitious roots in gymnosperms decreases with aging. While it is true that some efforts have been made to identify markers or/and regulators of the aging process and adventitious rooting, molecular mechanisms that regulate both processes are scarcely known, especially at protein level. This research evaluated qualitative and quantitative changes in protein accumulation during the adventitious rooting process of $P$. radiata stem cuttings, with different rooting capabilities. Beside, an analysis of morpho-anatomical changes was performed in stem cuttings with high and low rooting capabilities, during the adventitious rooting process. It was observed that juvenile 1-year-old stem cuttings rooted in a $100 \%$, while aged stem cuttings (3-year-old) presented only a $20 \%$ of rooting. According to the results of differential protein accumulation, univariate and multivariate analysis indicated that in total, 114 and 89 proteins were differentially accumulated in juvenile and aged cuttings, respectively. Also, identification of such proteins showed the presence of proteins related to cell wall organization and the presence of a protein related with proper distribution of auxin PIN transporter, both key in the new meristem formation process during adventitious rooting.
\end{abstract}

\section{Keywords}

Pinus radiata, Adventitious Rooting, Protein Accumulation, Aging 


\section{Introduction}

It is widely known that vegetative reproduction in plants is highly successful in early stages of plant development. In forestry species such as $P$. radiata, decrease in organ regeneration capability from differentiated somatic cells, is highly related to tree age and maturation stage [1]-[3]. However, desirable traits that qualify an individual as elite are expressed later in the plant life cycle, after the acquisition of reproductive capability. However, this acquisition, or this phase-change also implies a loss in morphogenic competence, specifically in the ability to produce adventitious roots [4]-[7]. This imposes the problem of having to select plant material from adult trees for vegetative multiplication, while clonal multiplication is an ability owned by juvenile plants.

The negative effects of aging on rooting have created the need to describe and characterize physiological markers for both processes. For aging, studies have been focused mainly in the relation between the loss of morphogenic competence and plant hormones. Endogenous content of indol-acetic acid (IAA) and abscisic acid (ABA) has been analyzed mainly in relation to different stages of the rooting process [8]-[10]. In the same way, higher polyamine concentration, such as spermidine and spermine, is associated to higher rates of morphogenic competence, including root development [11] [12].

On the other hand, molecular markers associated to adventitious rooting and aging are scarce, especially in relation to changes in morphogenic competence. However, some genes have been linked to the process of rooting in gymnosperms hypocotyls. Specifically, genes of the GRAS proteins family, such as SCARECROW-LIKE (SCL) [13] [14] and SHORT-ROOT (SHR) [15] are related to the process of rooting in Pinus contorta. Likewise, Brinker et al. [16] found an increase in the expression of the PINHEAD/ZWILLE gene through hypocotyls adventitious rooting in P. radiata. This indicates that these genes could be involved in the formation and maintenance of the undifferentiated state of the new meristem. Also, reports related with proteins associated to loss of morphogenic competence and aging are inexistent. Despite the obvious importance of proteins in the biology of development, the number of research published in relation to proteomic of forest trees is anecdotic [17]. This could be due to the problem imposed by gymnosperm as experimental systems, which includes big physical size, big genome, long generational cycles, difficulty in sample preparation and recalcitrance for genetic transformation. In trees, efforts made in relation to proteomic research are focused mainly in description of protein accumulated in wood forming tissue, especially in the Pinus genus [18]-[20], and during the process of water stress in Quercus ilex [21], Picea abies [22] and Populus cathayana [23]. These authors have found proteins related to photosynthesis, HSP/chaperone and redox homeostasis, which are related to the control of reactive oxygen species (ROS), and are key protein related to water stress. Despite the adverse effects of aging in forest improvement programs, research related to proteins associates to aging, and/or loss of morphogenic competence is scarce and corresponds mainly to annual plants such as Arabidopsis, and is related to lateral root production. In relation to this, Sorin et al. [24] reported that in 
Arabidopsis superroot mutants (sur1 and sur2), which are auxin over-producers and spontaneously generate adventitious roots, the auxin induces GH3-like protein is positively correlated with adventitious root number. In $P$. radiata, there is only one report indicating the differential accumulation of 16 proteins through hypocotyls adventitious rooting [25]. However, these peptides were not identified. In relation to aging and loss of morphogenic competence in gymnosperms, Chang et al. [26] reported that oxygenevolving enhancer 2 proteins (OEE2), RNA binding glycine-rich protein (RNP) and a thaumatin-like protein were differentially accumulated through different stages of reinvigoration of Sequoia sempervirens, performed through grafting. Also, Valledor et al. [27], combining transcriptomic and proteomic techniques, described changes in the accumulation/expression of 280 proteins and 176 genes, in mature and immature $P$. radiata needles with different morphogenic capabilities. According to the above, the following hypothesis was established indicating that $P$. radiata stem cuttings from donor plants with different morphogenic capabilities, exhibited different patterns of protein accumulation during the early stages of adventitious rooting. To test this hypothesis, changes in protein accumulation were evaluated through the utilization of bi-dimensional electrophoresis (2-DE), during the early stages of adventitious rooting of $P$. radiata stem cuttings of 1- and 3-year-old that posses differences in their morphogenic capabilities. In our previous work, we already describe changes in gene expression associated to ageing and morphogenetic competence through the rooting process.

\section{Material and Methods}

\subsection{Plant Material and Adventitious Rooting Procedure}

Plant material was obtained from Proplantas nursery S.A located in Bio-Bío region in central Chile $\left(36^{\circ} 37^{\prime} 25.87^{\prime \prime S}\right.$ and $\left.72^{\circ} 21^{\prime} 23.80^{\prime \prime} \mathrm{W}\right)$. Plant material corresponds to rootstock plants of 1- and 3-year-old from the same full-sib family, and cultivated under the same conditions of fertilization and watering. In brief, watering was applied daily through nebulized watering, fertilization consisted on $400 \mathrm{mg} \cdot \mathrm{L}^{-1}$ of $\mathrm{N}$ (with $\mathrm{NaNO}_{3}$, $\left(\mathrm{NH}_{4}\right)_{2} \mathrm{HPO}_{4}, \mathrm{CO}\left(\mathrm{NH}_{2}\right)_{2}$ and $\left(\mathrm{NH}_{4}\right)_{2} \mathrm{SO}_{4}$ as sources), $150 \mathrm{mg} \cdot \mathrm{L}^{-1}$ of $\mathrm{P}$ (with $\mathrm{KH}_{2} \mathrm{PO}_{4}$ and $\mathrm{Ca}\left(\mathrm{H}_{2} \mathrm{PO}_{4}\right)_{2}$ as sources), $100 \mathrm{mg} \cdot \mathrm{L}^{-1}$ of $\mathrm{K}$ (with $\mathrm{K}_{2} \mathrm{SO}_{4}, \mathrm{~K}_{2} \mathrm{CO}_{3}$ and $\mathrm{KH}_{2} \mathrm{PO}_{4}$ as sources), $40 \mathrm{mg} \cdot \mathrm{L}^{-1}$ of $\mathrm{Mg}$ with $\mathrm{MgSO}_{4}$ as source, $60 \mathrm{mg} \cdot \mathrm{L}^{-1}$ of $\mathrm{S}$ (with $\mathrm{MgSO}_{4}, \mathrm{~K}_{2} \mathrm{SO}_{4}$ and $\left(\mathrm{NH}_{4}\right)_{2} \mathrm{SO}_{2}$ as sources) and $80 \mathrm{mgL}^{-1}$ of $\mathrm{Ca}$ (with $\mathrm{CaCO}_{3}$ and $\mathrm{Ca}\left(\mathrm{H}_{2} \mathrm{PO}_{4}\right)_{2}$ as sources). Stem cuttings were rooted on the nursery of the Forestry Science Faculty of the Universidad de Concepción according to Proplantas S.A nursery protocol for container rooting. In brief: cuttings were washed with $0.5 \mathrm{~g} \cdot \mathrm{L}^{-1}$ of benomilo ${ }^{\oplus}$ solution to avoid fungal contamination. Then, cuttings were placed in containers with 88 cavities of $130 \mathrm{~cm}^{3}$ with pine bark compost as a substrate. Cuttings were irrigated three times a day to maintain foliage and substrate wet at field capacity. Rooting percentage was evaluated until younger cuttings reached $100 \%$ rooting.

The collection of plant material for protein extraction and anatomy analysis was performed at serial time points: 0 (T0), 5 (T1) and 15 days (T2) after cutting preparation. Plant material for protein extraction corresponds to $250 \mathrm{mg}$ of fresh stem from the 
base of the cuttings. The base of the stem cuttings were washed with distilled water and frozen in liquid nitrogen. Plant material was stored at $-80^{\circ} \mathrm{C}$ until protein extraction. For the anatomical analysis, the base of the stem cuttings were cut and soaked in formaldehyde-alcohol-acetic acid (FAA) until the histological cuts were performed.

\subsection{Protein Sample Preparation}

Protein isolation was performed with a tris-glycerol-SDS protocol, with a phenol purification step. In brief: $250 \mathrm{mg}$ were grounded in liquid nitrogen with a mortar and pestle. Aliquots of $250 \mathrm{mg}$ of frozen powder were placed in $400 \mathrm{uL}$ of extraction buffer (100 $\mathrm{mM}$ Tris- $\mathrm{HCl} \mathrm{pH} 8.0,5 \%$ SDS, $10 \%$ glycerol, $2 \mathrm{mM}$ PMSF and $10 \mathrm{mM}$ DTT) vortexed and incubated at $95^{\circ} \mathrm{C}$ for 5 minutes. Then, samples were incubated in ice $5 \mathrm{~min}$ and vortexed. Four hundred microliters of extraction buffer with $1.5 \mathrm{M}$ sacarose plus $400 \mathrm{uL}$ of saturated phenol were added to the samples. Samples were homogenized in a vortex and incubated at room temperature for 10 minutes. The homogenate was centrifuged 5 min at maximum speed (14.000 rpm). The supernatant was stored, while the pellet was re-extracted as described above. Both phenolic phases were mixed. Two volumes of 0.1 $\mathrm{M}$ ammonium acetate in methanol were added to the homogenate and stored at $-20^{\circ} \mathrm{C}$ overnight, to allow protein precipitation. Homogenate was centrifuged at $5000 \mathrm{~g}, 4^{\circ} \mathrm{C}$ for 5 minutes and the supernatant was eliminated. Pellet was washed twice with cold $100 \%$ and $90 \%$ acetone respectively; pellet was sonicated to dissolve proteins. Finally, the pellet was allowed to air-dry and resuspended in rehydration buffer ( $8 \mathrm{M}$ urea, $2 \%$ CHAPS and $0.5 \%$ ampholites), samples were centrifuged at maximum speed for 5 min and supernatant was saved. Total soluble protein concentration was measured with the bicinchoninic acid (BCA) method. After protein quantification, DTT was added to reach a final concentration of $8 \mathrm{mM}$.

\subsection{Bi-Dimensional Electrophoresis (2-DE)}

For each stem cutting age and rooting time, 100 ug of protein were loaded onto precast IPG strips (pH 5 - 8 linear gradient, 7 cm; Bio-Rad, Hercules, USA), and four biological replicates were done for each time point and cutting age. Isoelectric focusing (Ettan-IPGphor isoelectric focusing system, Amersham Biosciences) was performed under the following conditions: passive rehydration for $12 \mathrm{~h}$, followed by a $1 \mathrm{~h}$ and $10 \mathrm{~min}$ at $150 \mathrm{~V}$, a gradual increase to $250 \mathrm{~V}$ for $20 \mathrm{~min}$ and finally $10,000 \mathrm{Vh}$ at $4000 \mathrm{~V}$. The focused strips were stored at $-20^{\circ} \mathrm{C}$. Before second separation step, IEF strips were incubated twice for $15 \mathrm{~min}$ each time in equilibrium buffer ( $6 \mathrm{M}$ urea, $30 \% \mathrm{w} / \mathrm{v}$ glycerol, $2 \%$ $\mathrm{w} / \mathrm{v}$ SDS in $0.05 \mathrm{M}$ Tris- $\mathrm{HCl}$ buffer $\mathrm{pH} 8.8$ ) containing $1 \%$ DTT in the first equilibration step and $4 \%$ iodoacetamide in the second step.

In the second dimension, proteins were separated on 13.5\% SDS-PAGE using a Mini-Protean Tetra Cell electrophoresis system (Bio-Rad, Hercules, USA) operating at $30 \mathrm{~V}$ for $30 \mathrm{~min}$ and $90 \mathrm{~V}$ until the front dye reached the end of the gel. Following 2-DE, gels were stained with flamingo fluorescent stain (Bio-Rad, Hercules, USA) and imaged with a Typhoon Trio scanner (Amersham Biosciences) for fluorescent samples. 


\subsection{Experimental Design, Statistic Analysis and 2-DE Data Analysis}

Digitalized gel images were analyzed with PDQuest 8 software (Bio-Rad, Hercules, USA). Spot-by-spot visual validation of automated analysis was done to increase the reliability of the matching [28]. Normalized spot volumes (individual spot intensity/normalization factor) calculated for each gel based on total quantity in valid spots were determined and used for statistical calculations of protein expression levels. Experimental $p I$ was determined using a 5-8 linear scale over the total length of the IPG strip. $M_{r}$ values were calculated by mobility comparisons with protein standards markers run in a separate lane in the gel.

Missing spot volumes were estimated from the data set employing a sequential K-Nearest Neighbor (KNN) algorithm using the R 2.14.1 environment [29]. This procedure was performed only if the spot was present in at least 3 of the 4 replicates. After missing imputation, total spot intensity per gel was used to normalize spot intensities (\% of individual spot intensity/ $\Sigma \%$ spot intensity of each gel) to compensate for variations between gel replicates.

Selection of differentially abundant protein spots was performed through a repeated measurement model; the best variance and co-variance structure was selected by selecting the lower Akaike index between the different structures tested. Both time and rootstock plant age were set as fixed effects, SAS 9.1 software was used for this analysis. Also, multivariate analysis was done. A partial least square discriminant analysis (PLS-DA) was applied to the data set corresponding to 1-year-old and 3-year-old rootstock plants, scores and loading plots were obtained using the mixOmics [30] package from the R 2.14.1 environment. VIP values (variable importance on projection) were obtained using the PLS package also from $\mathrm{R}$ 2.14.1. Spot selection according to the VIP index was achieved following the "greater than 1 rule", since the average squared VIP scores equals 1 . This is generally used as a criterion for variable selection [31].

\subsection{On-Gel Protein Digestion and LC-MS/MS Analysis}

According to the results, 16 spots were selected for identification, which were manually excised from the gel. Spots were digested following the protocol described by Shervchenko et al. [32] with minor modifications. Spots were distained with two washes at $37^{\circ} \mathrm{C}$ for 30 minutes in $200 \mathrm{mM}$ ammonium bicarbonate in $40 \%$ (v(v) acetonitrile (ACN). Then spots were washed twice with $20 \mathrm{uL}$ of $25 \mathrm{mM}$ ammonium bicarbonate to be dehydrated with $20 \mathrm{uL}$ of $100 \mathrm{mM}$ ammonium bicarbonate/50\% (v/v) ACN followed by a wash of $20 \mathrm{uL} \mathrm{ACN}$. Spots were dried for 10 minutes at ambient temperature. For digestion, gels were rehydrated in $20 \mathrm{uL}$ of $25 \mathrm{mM}$ ammonium bicarbonate solution with $12.5 \mathrm{ng} / \mathrm{uL}$ tripsin (sequencing grade, Promega) and then incubated at $37^{\circ} \mathrm{C}$ over night. Peptides were extracted from the gels by adding $30 \mathrm{uL}$ of $50 \%-90 \% \mathrm{ACN} / 1 \%$ TFA, then were dried and purified in C-18 micro-columns (ZipTip, Millipore, Madrid, España).

Peptides were deposited in a MALDI plate using the dry drop method (ProMS, Ge- 
nomic Solutions, Chelmsford, MA, USA) and CHCA as matrix at $\mathrm{mg} / \mathrm{mL}$ in $70 \% \mathrm{ACN}$, $0,1 \%$ TFA. Samples were analyzed in a mass spectrometer analyzer MALDI-TOF-TOF 4700 (Applied Biosystems, Foster City, CA, USA) in a $800-4000 \mathrm{~m} / z$ range, with an acceleration voltage of $20 \mathrm{k} \mathrm{V}$, in replectron mode with a delayed extraction of $120 \mathrm{~ns}$. The specter was internally calibrated with trypsin auto-lysis peptides. The three most abundant ions were subjected to spectrometry analysis in mass tandem (MS/MS). An identification search was performed through peptidic fingerprint (PMF) (MS plus MS/MS) in non-redundant data base NCBI, using the GPS Explorer v 3.5 software (Applied Biosystems) plus the MASCOT (Matrix Science, London, UK) search engine. The following parameters were allowed: taxonomy restriction at Viridiplantae, cleavage allowed, mass tolerance at $100 \mathrm{ppm}$ in MS and 0.5 Da for MS/MS data, fixed modification of cysteine carbamidomethilation and methionine oxydation as variable modification. PMF matches coincidences was based in MOWSE score (Molecular Weight SEarch) and confirmed by precise superposition of matching peptides with higher peaks from the mass spectra and protein score with a $P$ value lower than 0.05 . Combination between PMF and MS/MS ion scores allowed the coincidence of significant peptides for 8 of the selected spots. Access numbers are referred according to SWISS-Prot or NCBI while theorical $M r$ (in $\mathrm{kDa}$ ) and the $p I$ of homologous proteins were calculated through the $M r / p I$ tool available at Expasy, http://www.expasy.ch/tools/pi_tool.html). Molecular function was inferred from Gene and Genome Encyclopedia (KEGG).

\section{Results}

\subsection{Rooting Capability and Morphological Characteristics of 1- and 3-Year-Old Stem Cuttings}

Juvenile (1-year-old) and aged (3-year-old) P. radiata stem cuttings were evaluated through adventitious rooting process. While almost $100 \%$ of juvenile stem cuttings developed roots within two month of the rooting process, only $18.8 \%$ of aged cuttings showed this response within the same period of time (Table 1). At histological level,

Table 1. Anatomical characteristics of stems cuttings of juvenile (1-year-old) and aged (3-yearold) Pinus radiata rootstock plants, and rooting capability after 2 months.

\begin{tabular}{ccc}
\hline Anatomical & \multicolumn{2}{c}{ Rootstock plants age } \\
\cline { 2 - 3 } Characteristics & 1-year-old & 3-year-old \\
\hline Total diameter $(\mu \mathrm{m})$ & $2355.6 \pm 209.2(\mathrm{~b})$ & $3717.5 \pm 170.7(\mathrm{a})$ \\
Xylem diameter $(\mu \mathrm{m})$ & $461.7 \pm 74.2(\mathrm{~b})$ & $811.4 \pm 13.4(\mathrm{a})$ \\
Phloem diameter $(\mu \mathrm{m})$ & $119.6 \pm 10.2(\mathrm{a})$ & $149.1 \pm 12.0(\mathrm{a})$ \\
Periderm width $(\mu \mathrm{m})$ & $81.5 \pm 8.5(\mathrm{~b})$ & $117.5 \pm 1.3(\mathrm{a})$ \\
& Rooting capability & $18.8 \pm 0.9(\mathrm{~b})$ \\
\hline
\end{tabular}

Values \pm standard deviation $(\mathrm{n}=5)$, different letters correspond to significant differences according to Student's $t$ test $(\mathrm{P}<0.05)$. 
1-year-old stem cuttings (Figure 1(a)) presented a thickening at the base of the cuttings, at day 15 and it was possible to observe the initial formation of the new meristem (Figure $1(\mathrm{~b})$ ), and at day 30th it was possible to observe the emerging root primordia (Figure 1(c)). Otherwise, 3-year-old cuttings (Figure $1(\mathrm{~d})$ ) presented the same response 30 days after the beginning of the rooting process (Figure 1(f)), while at day 15 it was not possible to observe any response from these cuttings (Figure 1(e)). Three-year-old stem cuttings showed an increase in the total diameter, xylem diameter and periderm width. On the contrary, younger cuttings showed a lower degree of tissue development (Table 1).

\subsection{Changes in the Protein Accumulation through Adventitious Rooting}

According to the differential protein accumulation analysis, 205 total spots were detected including gels from 1- and 3-year-old cuttings. Table 2 shows the number of total spots detected by replicate group and the number of common and exclusive (qualitative differences) spots between the two types of cuttings. Out of the total spots present in all gels, 184 were common between young and old cuttings while 15 and 6 spots were only detected in 1- and 3-year-old cuttings, respectively.

Univariate and multivariate analysis were performed in the data set to select the differentially abundant proteins. For the univariate analysis 33 and 20 protein spots were differentially accumulated in 1- and 3-year-old cuttings, respectively. Due to the fact that univariate statistical tools treat each spots as an independent variable, it was important to perform a multivariate analysis, which consider a group of variables together rather than one variable at a time. For this reason, we performed a partial least square discriminant analysis (PLS-DA) on 1- and 3-year-old cuttings data set, separately. As

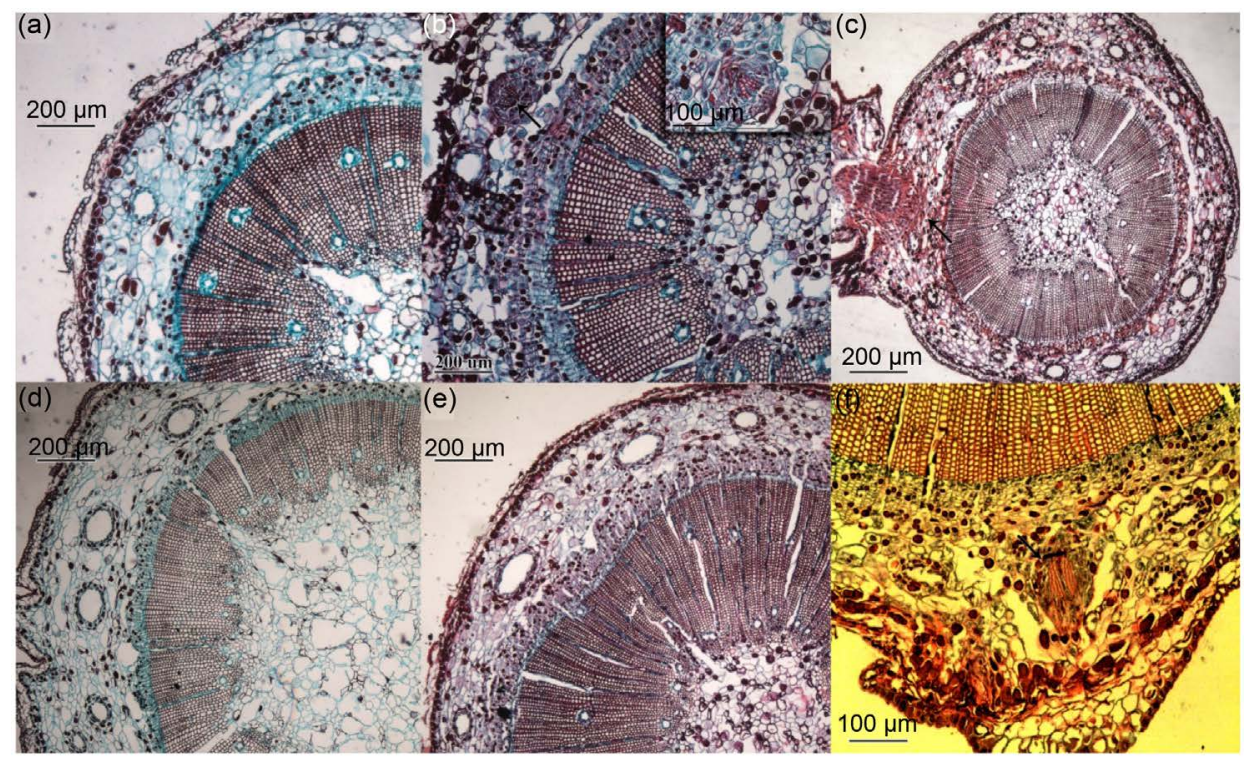

Figure 1. Cross-sections of $P$. radiata stem cuttings through the first stages of adventitious rooting. Juvenile 1-year-old cuttings (a)-(c), from 0 (a), 15 (b) and 30 days (c). Aged 3-year-old cuttings (d)-(f), from 0 (d), 15 (e) and 30 days (f). Arrows indicate the formation of the new meristem. Bar represent $200 \mu \mathrm{m}$ in figures (a)-(e); in (f) bar represents $100 \mu \mathrm{m}$. (a), (b), (d) and (e) were taken with a 10× magnification, (c) was taken with a $4 \times$ magnification and figure $F$ was taken with a $40 \times$ magnification. 


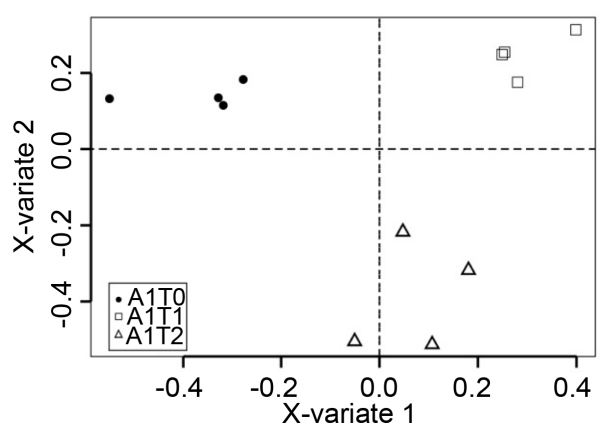

(a)

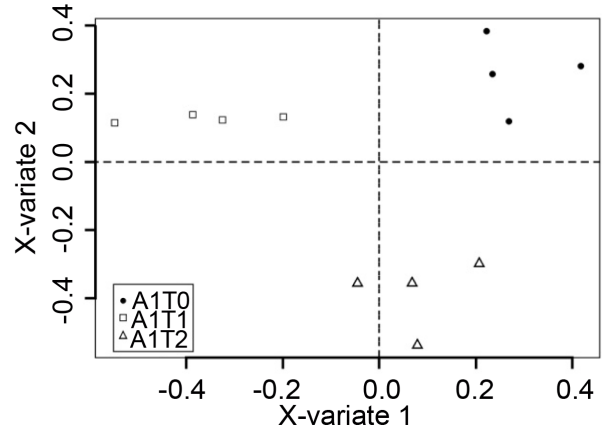

(b)

Figure 2. Score plot of PLS-DA analysis showing separation of the samples according to adventitious rooting time points: 0 (circle), 5 (square) and 15 days (triangle) for cuttings harvested from 1-year-old (A) and 3-year-old (B) rootstock plants.

Table 2. Number of detected spots in different rootstock plant ages. Average spot is indicated as mean spots detected \pm standard deviation. Plant material corresponds to cuttings harvested from 1-year-old (A1) and 3-year-old (A3) rootstock plants, which were evaluated through the rooting processes at time point 0 (T0), 5 (T1) and 15 days (T2).

\begin{tabular}{cccccc}
\hline \multirow{2}{*}{ Plant material } & \multicolumn{2}{c}{ Number of spots } & \multicolumn{2}{c}{ Consistent spots } \\
\cline { 2 - 5 } & Min/Max & Average & Total & Common & Qualitative differences \\
\hline A1T0 & $107 / 139$ & $124.2 \pm 3.6$ & & & 15 \\
A1T1 & $86 / 119$ & $105.7 \pm 3.8$ & 199 & 184 & \\
A1T2 & $84 / 131$ & $112.2 \pm 4.9$ & & & 6 \\
A3T0 & $95 / 156$ & $127.7 \pm 6.3$ & & & \\
A3T1 & $110 / 151$ & $125.6 \pm 4.5$ & 190 & 184 & \\
A3T2 & $122 / 141$ & $127.5 \pm 2.3$ & & & \\
\hline
\end{tabular}

observed in Figure 2, the PLS-DA was able to group the samples according to the different times of adventitious rooting for both types of cuttings (Figure 2(a) and Figure 2(b)). It was also possible to select the most discriminant spots, which have greater influence in sample separation. To achieve this task we applied the VIP algorithm, this provides a condensed summary statistic of each spot overall influence on sample separation. According to this index, 81 and 69 spots showed VIP scores greater than 1 in 1- and 3-year-old cuttings, respectively, and 30 spots were common to both kinds of cuttings. Finally, out of the 33 spots differentially expressed in younger cuttings, 28 were also represented within the 81 spots selected by the multivariate analysis. On the same way, out of the 20 spots differentially accumulated in older cuttings, 13 were within the 69 spots selected by the PLS analysis.

From differential spots, 13 spots were extracted and sequenced, within these, 8 were successfully identified (Figure 3). From the 8 identified spots, 4 spots were related to more than one peptide which can indicate co-migration of proteins, which happens when all identified proteins within the same spots have the same $M r$ and $p I$. For example, in the spot 5403, the UDP-glucoranate 4-epinerase and taxidiene synthase protein were identified (Table 3 ). In relation to the protein identification, it was observed that 
Table 3. List of differentially expressed proteins between Pinus radiata cuttings from 1- and 3-year-old rootstock plants, during the first stages of the adventitious rooting process.

\begin{tabular}{|c|c|c|c|c|c|c|c|c|c|c|}
\hline \multirow{2}{*}{ SSP } & \multicolumn{2}{|c|}{ Experimental } & \multicolumn{2}{|c|}{ Theorical } & \multirow{2}{*}{ Protein } & \multirow{2}{*}{$\begin{array}{l}\text { Action } \\
\text { pathway }\end{array}$} & \multirow{2}{*}{$\begin{array}{l}\text { Reference } \\
\text { organism }\end{array}$} & \multirow{2}{*}{$\begin{array}{c}\text { Access } \\
\mathbf{N}^{\circ}\end{array}$} & \multirow{2}{*}{$\begin{array}{l}\text { Sequence } \\
\text { coverage } \\
(\%)\end{array}$} & \multirow{2}{*}{ Score } \\
\hline & $M_{r}$ & $p I$ & $M_{r}$ & $p I$ & & & & & & \\
\hline 6306 & 22.9 & 6.7 & 1.2 & 6.0 & $\begin{array}{l}\text { Oxygen-evolving enhancer } \\
\text { protein } 2 \text { (Fragment) }\end{array}$ & Photosynthesis & Pinus pinaster & PSBP_PINPS & 100 & 83 \\
\hline \multirow[t]{2}{*}{6207} & 20.5 & 6.6 & 15.6 & 11.3 & Histone H3-like 5 & $\begin{array}{l}\text { Choromosome } \\
\text { and other proteins }\end{array}$ & $\begin{array}{c}\text { Arabidopsis } \\
\text { thaliana }\end{array}$ & H3L5_ARATH & 5 & 26 \\
\hline & & & & & $\begin{array}{c}\text { Protein ROOT HAIR } \\
\text { DEFECTIVE } 3 \text { homolog } 2\end{array}$ & & Oryza japonica & RHD32_ORYSJ & 1 & 16 \\
\hline \multirow[t]{2}{*}{8401} & 24.3 & 7.2 & 193.2 & 5.3 & Clathrin heavy chain 1 & Endocytosis & $\begin{array}{c}\text { Arabidopsis } \\
\text { thaliana }\end{array}$ & CLAH1_ARATH & 1 & 39 \\
\hline & & & & & $\begin{array}{l}\text { Iron-sulfur assembly protein } \\
\text { IscA-like } 3 \text {. mitocondrial }\end{array}$ & & $\begin{array}{c}\text { Arabidopsis } \\
\text { thaliana }\end{array}$ & ISAM3_ARATH & 13 & 22 \\
\hline \multirow[t]{3}{*}{8711} & 47.3 & 7.7 & 26.3 & 8.3 & $\begin{array}{c}\text { Agamous-like MADS-box } \\
\text { protein AGL17 }\end{array}$ & & $\begin{array}{l}\text { Arabidopsis } \\
\text { thaliana }\end{array}$ & AGL17_ARATH & 5 & 26 \\
\hline & & & & & $\begin{array}{l}\text { Probable glycerophosphoryl } \\
\text { diester phosphodiesterase } 2\end{array}$ & $\begin{array}{l}\text { Glycerophospholipids } \\
\text { methabolism }\end{array}$ & $\begin{array}{c}\text { Arabidopsis } \\
\text { thaliana }\end{array}$ & GLPQ2_ARATH & 2 & 24 \\
\hline & & & & & Putative pectate lyase 11 & $\begin{array}{c}\text { Interconversion of } \\
\text { pentose and glucoranate }\end{array}$ & $\begin{array}{c}\text { Arabidopsis } \\
\text { thaliana }\end{array}$ & PLY11_ARATH & 4 & 23 \\
\hline 2512 & 31.2 & 5.5 & 1.4 & 5.8 & Unknown protein 1 (Fragment) & & $\begin{array}{l}\text { Vitis } \\
\text { rotundifolia }\end{array}$ & UP01_VITRO & 100 & 41 \\
\hline \multirow[t]{2}{*}{5403} & 29.3 & 6.1 & 48.1 & 9.9 & $\begin{array}{l}\text { UDP-glucuronate } \\
\text { 4-epimerase } 2\end{array}$ & $\begin{array}{l}\text { Sugar and sucrose } \\
\text { methabolism }\end{array}$ & $\begin{array}{c}\text { Arabidopsis } \\
\text { thaliana }\end{array}$ & GAE2_ARATH & 3 & 15 \\
\hline & & & & & Taxadiene synthase & Diterpenoid biosynthesis & Taxus baccata & TASY_TAXBA & 3 & 33 \\
\hline 1505 & 34.5 & 5.4 & 26.7 & 5.6 & (DL)-glycerol-3-phosphatase 2 & Riboflavin methabolism & $\begin{array}{c}\text { Arabidopsis } \\
\text { thaliana }\end{array}$ & GPP2_ARATH & 5 & 26 \\
\hline 3304 & 20.5 & 5.6 & 84.2 & 6.6 & $\begin{array}{c}\text { Probable RNA-dependent } \\
\text { RNA polymerase } 1\end{array}$ & & Oryza sativa & RDR1_ORYSJ & 1 & 18 \\
\hline 2601 & 40.5 & 5.6 & - & - & No hit & & - & - & - & - \\
\hline 3303 & 21.8 & 5.6 & - & - & No hit & & - & - & - & - \\
\hline 1702 & 47.5 & 5.3 & - & - & No hit & & - & - & - & - \\
\hline 3601 & 41.5 & 5.7 & - & - & No hit & & - & - & - & - \\
\hline
\end{tabular}

the spot 6207, which corresponds to a Histone H3-like and a ROOT HAIR DEFECTIVE 3 proteins, increased their level during the first 5 days for juvenile and aged cuttings (Table 4). However, this spot was increased 11.09 times in juvenile cuttings compared with aged cuttings, which presented only 3.27-fold increase during the first 5 days of the adventitious rooting process. On the contrary, the spot 6306, that corresponds to a Oxygen-evolving enhancer protein 2 presented a 6.78 -fold decrease in accumulation during the first 5 days of the process in juvenile cuttings, while in aged cuttings this protein was increase 1.38-fold during the same period. Also, the spot 8401 that was identified as a clathrin long chain and a Iron-sulfur assembly IsA-like 3, pre- 


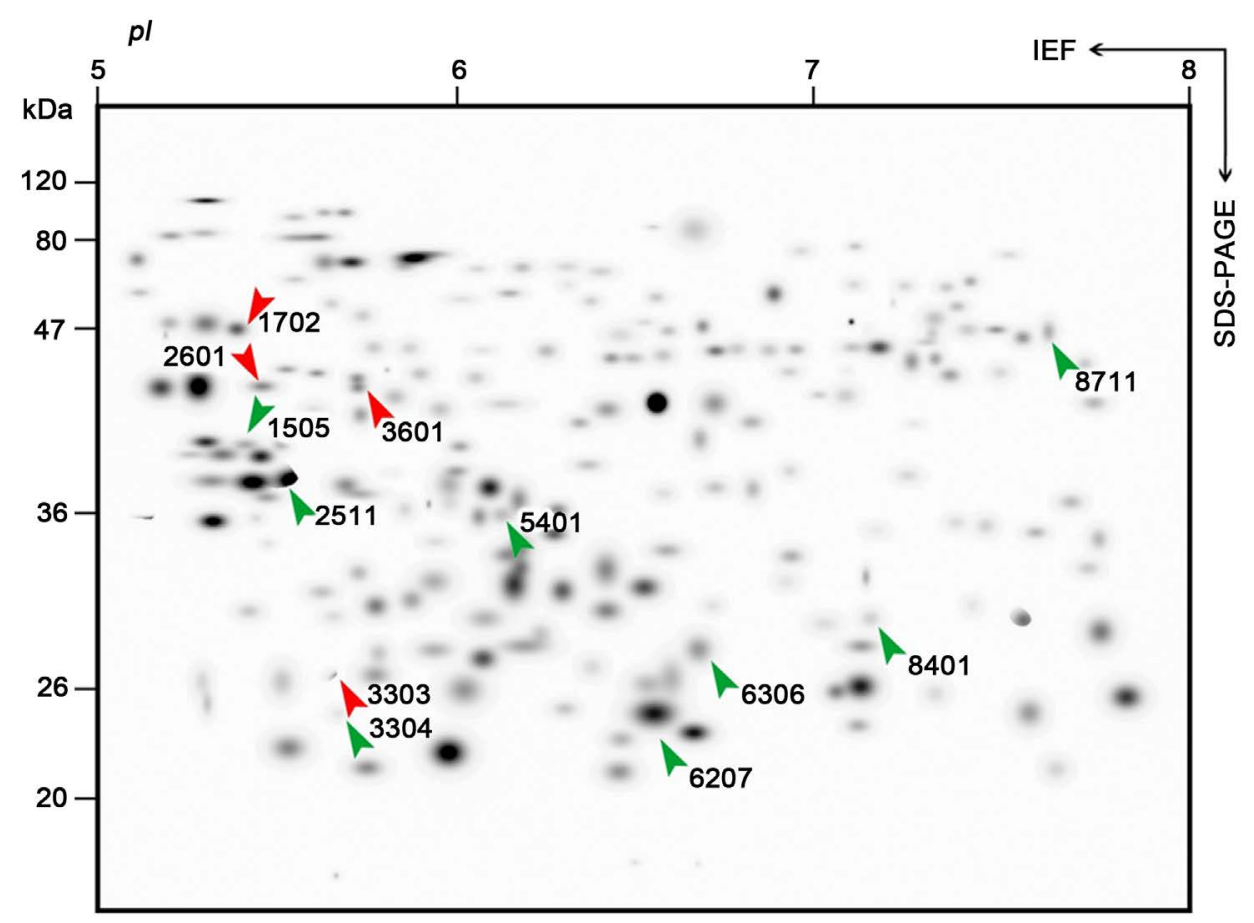

Figure 3. Master gel that combines spots found in Pinus radiata stem cuttings from juvenile (1-year-old) and aged (3-year-old) rootstock plants, for 0,5 and 15 days since the beginning of the adventitious rooting process. Numbers shows the spots subjected to sequencing. Green arrows indicate identified spots, while red arrows are non-identified spots.

Table 4. Changes in protein spots (SPP) accumulation between Pinus radiata cuttings from 1(A1) and 3-year-old (A3) rootstock plants, during the first stages of adventitious rooting, evaluated at time point 0 (T0), 5 (T1) and 15 days (T2). Mean values \pm standard error of the normalized spot volumes (\% total intensity of each spot).

\begin{tabular}{ccccccc}
\hline \multirow{2}{*}{ SPP } & \multicolumn{5}{c}{ Normalized spot intensity } \\
\cline { 2 - 7 } & A1T0 & A1T1 & A1T2 & A3T0 & A3T1 & A3T2 \\
\hline $\mathbf{6 3 0 6}$ & $0.69 \pm 0.28$ & $0.10 \pm 0.05$ & $0.0 \pm 0.0$ & $0.46 \pm 0.19$ & $0.64 \pm 0.11$ & $0.07 \pm 0.04$ \\
$\mathbf{6 2 0 7}$ & $0.41 \pm 0.24$ & $4.58 \pm 0.75$ & $3.22 \pm 0.47$ & $0.90 \pm 0.29$ & $2.97 \pm 1.48$ & $2.06 \pm 1.03$ \\
$\mathbf{8 4 0 1}$ & $0.23 \pm 0.08$ & $0.16 \pm 0.11$ & $0.0 \pm 0.0$ & $0.14 \pm 0.05$ & $0.46 \pm 0.07$ & $0.05 \pm 0.05$ \\
$\mathbf{8 7 1 1}$ & $0.34 \pm 0.07$ & $0.0 \pm 0.0$ & $0.08 \pm 0.05$ & $0.50 \pm 0.14$ & $0.29 \pm 0.15$ & $0.31 \pm 0.14$ \\
$\mathbf{2 5 1 2}$ & $7.39 \pm 3.69$ & $2.97 \pm 1.48$ & $0.35 \pm 0.17$ & $8.62 \pm 1.84$ & $3.10 \pm 1.04$ & $0.18 \pm 0.11$ \\
$\mathbf{5 4 0 3}$ & $0.61 \pm 0.24$ & $0.55 \pm 0.19$ & $1.33 \pm 0.15$ & $0.96 \pm 0.31$ & $1.38 \pm 0.08$ & $1.12 \pm 0.14$ \\
$\mathbf{1 5 0 5}$ & $3.58 \pm 0.64$ & $0.0 \pm 0.0$ & $2.82 \pm 0.66$ & $3.71 \pm 0.77$ & $3.88 \pm 0.87$ & $0.0 \pm 0.0$ \\
$\mathbf{3 3 0 4}$ & $0.16 \pm 0.08$ & $0.0 \pm 0.0$ & $0.0 \pm 0.0$ & $0.0 \pm 0.0$ & $0.20 \pm 0.08$ & $0.19 \pm 0.01$ \\
$\mathbf{2 6 0 1}$ & $1.12 \pm 0.42$ & $0.26 \pm 0.11$ & $0.0 \pm 0.0$ & $0.22 \pm 0.01$ & $0.65 \pm 0.19$ & $0.18 \pm 0.07$ \\
$\mathbf{3 3 0 3}$ & $0.51 \pm 0.24$ & $0.27 \pm 0.18$ & $0.49 \pm 0.31$ & $0.18 \pm 0.10$ & $0.54 \pm 0.12$ & $0.17 \pm 0.10$ \\
$\mathbf{1 7 0 2}$ & $0.92 \pm 0.25$ & $0.54 \pm 0.23$ & $0.51 \pm 0.34$ & $0.18 \pm 0.11$ & $1.36 \pm 0.37$ & $0.0 \pm 0.0$ \\
$\mathbf{3 6 0 1}$ & $0.35 \pm 0.01$ & $0.27 \pm 0.05$ & $0.44 \pm 0.06$ & $0.21 \pm 0.01$ & $0.28 \pm 0.05$ & $0.30 \pm 0.11$ \\
\hline
\end{tabular}


sented in juvenile cuttings a decrease in accumulation until be undetected at day 15, while in 3-year-old cuttings a 3 -fold initial increase was observed, during the adventitious rooting process.

\section{Discussion}

According to the adventitious rooting analysis, it was confirmed that aged stem cuttings (3-year-old) presented a clear decrease in their rooting capability. On the contrary, almost $100 \%$ of juvenile $P$. radiata cuttings rooted during the evaluated period (2 months). This indicates that within a period of three years, it is possible to observe the effects of tree aging, which translates mainly in the loss of rooting capability [33] [34]. These results are in agreement with several researches that indicate that the effects of ontogenic aging can be observed before the flowering process [33]. This indicates that in gymnosperms such as $P$. radiata, loss of morphogenetic competence can occur early in the plant life cycle, not necessarily associated to flowering. This process should be taken into account for clonal multiplication practices in nurseries.

In relation to the anatomic analysis, it is possible to observe that, in 1-year-old cuttings, the initial formation of the radicular meristem that will generate the adventitious root can be identified within the first 15 days of the rooting process (Figure 1(b)). On the other hand, in 3-year-old cuttings this initial formation can be observed after 30 days (Figure 1(f)), indicating a delay in the process of formation and expression of the meristem. In the same way, greater development of secondary tissue was observed in 3-year-old cuttings compared to juvenile cuttings. According to Greenwood et al. [7], this formation of secondary tissue could constrain the development and expression of the new meristem. Beside differences at anatomical level, the protein accumulation was also different between both kinds of cuttings and stages of adventitious rooting.

From the analysis of differential protein accumulation, it was possible to observe that from the 205 detected spots for both types of cuttings, 114 and 89 spots were differentially accumulated in 1- and 3-year-old cuttings, respectively. These results show that juvenile cuttings possess a higher amount of proteins that can modify their accumulation during the adventitious rooting process. This could indicate that 1-year-old cuttings can generate greater changes in protein accumulation and adjust to the demands of the new forming meristem. Also, this could indicate that juvenile cuttings have a higher number of active metabolic pathways [27].

According to the analysis of spots present in both kinds of cuttings, it is observed that 1 -year-old cuttings have 15 proteins that are exclusive to this type of cutting, while the 3-year-old ones only have 6 spots (Table 2). These proteins that are exclusive to each type of plant material could indicate responsible proteins of the differential behavior during adventitious rooting. In relation to identified proteins, it is observed that the spot 6207 belongs to a Histone H3-like protein plus a ROOT HAIR DEFECTIVE 3 (RHD3), which increases their accumulation in juvenile cuttings during the first 5 days of adventitious rooting. The Histone $\mathrm{H} 3$ protein, is one of the five proteins involved in chromatin structure. It is expressed mainly in juvenile organs with increase in mitotic 
activity, together with histone $\mathrm{H} 4$ [35]-[37]. In relation to adventitious rooting, Brinker et al. [16] observed an increase in the expression of the histone $\mathrm{H} 3$ gene after 6 to 8 hours of adventitious rooting induction in Oryza sativa, indicating that histone $\mathrm{H} 3$ is an specific marker of the $S$ phase of cell cycle [38] [39]. The previous statement could be in agreement with the results found in this research in relation to the increase in the accumulation of histone $\mathrm{H} 3$ protein in juvenile cuttings, and this could indicate an entrance to the cell cycle of the cells involved in the formation of the new meristem.

Likewise, the RHD3 protein presented the same behavior than histone H3. This gen could have a function in cell enlargement during growth of radicular hairs in Arabidopsis, because rhd 3 mutants displayed an increase in the proportion of cytoplasm and reduction in the vacuole size, particularly affecting the radicular hair expansion phase [40] [41]. RHD3 could also have a function in cell wall biosynthesis and actin organization. Arabidopsis mutants showed a dramatic reduction in thickness of the secondary cell wall [42], which is an essential process for cellular expansion. Besides RHD3 other protein with functions in cell wall and radicular hair elongation was identified, the glycerophosphoryl diester phosphodiesterase 2 (GPD), identified in the spot 8711 . This protein showed a decrease of 3.87-fold in accumulation since the beginning of the rooting process until day 15 in juvenile cuttings. While it is true that the function of this protein has not been described in detail, researches have indicated that the SHV3 gene that encodes for a similar anchor-GPI protein and posses two GPD domains repeated in tandem, is required for root hairs elongation [43]. Mutants of this gene developed abnormal root epidermal cells, abnormal root hairs, abnormal cellulose deposition, which together with the localization of this gene in the outer side of the plasmatic membrane, suggest a function of $S H V 3$ and GPD in the organization of primary cell wall [44] [45]. It has been described in Arabidopsis a re-arrangement of the cell wall during the formation of lateral roots as consequence of division and cell enlargement rapid decrease in the accumulation of this protein in juvenile cuttings could be due to a need to generate tissue with a cell wall less developed, especially in $P$. radiata woody cuttings, allowing the development and expression of new roots.

Otherwise, a clathrin heavy chain $(\mathrm{CHC})$ protein was also identified, and this protein presented the same behavior as GPD in both types of cuttings. Clathrin is a complex of proteins in the shape of a trisquel consisting on heavy chains ( $\mathrm{CHC}$ ) and light chains (CLC) forming a lattice. Clathrin plays a major role in endocytosis, vesicle formation, protein abundance in plasmatic membrane and in the trans-Golgi network during signaling events [46] [47]. Specifically, clathrin is essential for the distribution of PIN proteins, indicating that auxin transport and its signaling is highly dependent of clathrin mediated endocytosis [48]-[50]. However, according to several research, auxin acts as an active repressor of endocytosis [51] [52], and this is in agreement with results found regarding a decrease in the accumulation of CHC. Thus, clathrin mediated endocytosis is required for correct location of PIN proteins, which is required for basipetal auxin transport. On the other hand, the cut made when the cuttings are being collected produces an accumulation of this hormone in the base of the cutting, acting as a signal for 
the beginning of the adventitious rooting induction phase [10] [53] [54], inhibiting endocytosis and explaining the decrease in the accumulation of this protein during the early phases for adventitious rooting.

According to the results, both juvenile and aged cuttings showed a decrease in the accumulation of agamous-like MADS-box protein (AGL17), identified in the spot 194. Genes that belong to the MADS-box family play a role during floral development, so their expression in restricted to floral organs [55] [56]. However, there are reports that indicate that a small portion of the genes that belong to this family are also expressed in vegetative organs [57]. Specifically, it has been reported that the AGL17 gene it is expressed in Arabidopsis roots [58], indicating that this gene could be involved in the formation of this organ. However, the expression of $A G L 17$ is restricted to the root epidermis, from the end of the proliferation zone until the elongation zone, including cells that have ceased their proliferation. It has not been observed the expression of this gene neither during the formation of root primordial nor during embryogenesis, indicating that this gene is not involved during the early phases of specification of cellular destiny [59]. The previous is in agreement with the decrease of the accumulation of this protein, especially in juvenile cuttings during early stages of adventitious rooting.

Finally, this research provides a characterization of proteins involved in the formation of adventitious roots on $P$. radiata stem cuttings and how this process is influenced by aging of rootstock plants. According to the results obtained in this research, in comparison to 1-year-old juvenile cuttings, a delay in 3-year-old cuttings rooting process was observed; concomitant with changes at anatomical level and in the protein accumulation pattern,. Besides, proteins involved in the formation and organization of cell wall were identified, indicating that this protein could be essential for the formation of adventitious roots.

\section{Acknowledgements}

The authors of this manuscript would like to thank to Proplantas Nursery S.A, INNOVA BIOBIO research project $\mathrm{n}^{\circ} 12.121$ and CONICYT scholarships.

\section{References}

[1] Greenwood, M. and Hutchison, K. (1993) Maturation as a Developmental Process. In: Ahuja, M. and Libby, W., Eds., Clonal Forestry I, Springer-Verlag, Berlin Heidelberg, 277. http://dx.doi.org/10.1007/978-3-642-84175-0_3

[2] Diaz-Sala, C., Hutchinson, K. and Greenwood, M.G. (1996) Maturation-Related Loss in Rooting Competence by Loblolly Pine Stem Cuttings: The Role of Auxin Transport, Metabolism and Tissue Sensitivity. Physiologia Plantarum, 97, 481-490. http://dx.doi.org/10.1111/j.1399-3054.1996.tb00507.x

[3] Day, M.E., Greenwood, M.G. and White, A.S. (2001) Age-Related Changes in Foliar Morphology and Physiology in Red Spruce and Their Influence on Declining Photosynthesis and Productivity with Tree Age. Tree Physiology, 21, 1195-1204. http://dx.doi.org/10.1093/treephys/21.16.1195

[4] Diego, L., Berdasco, M., Fraga, M., Cañal, M.J., Rodríguez, R. and Castresana, C. (2004) A 
Pinus radiata AAA-ATPase, the Expression of Which Increases with Tree Ageing. Journal of Experimental Botany, 55, 1597-1599. http://dx.doi.org/10.1093/jxb/erh171

[5] Browne, R., Davidson, C., Steeves, T. and Dunstan, D. (1997) Effects of Ortet Age on Adventitious Rooting of Jack Pine (Pinus banksiana) Long-Shoot Cuttings. Canadian Journal of Forest Research, 27, 91-96. http://dx.doi.org/10.1139/x96-160

[6] Ballester, A., San-José, M.C., Vidal, N. and Vieitez, A. (1999) Anatomical and Biochemical Events during in Vitro Rooting of Microcuttings from Juvenile and Mature Phases of Chestnut. Annals of Botany, 83, 619-630. http://dx.doi.org/10.1006/anbo.1999.0865

[7] Greenwood, M.S., Cui, X. and Xu, F. (2001) Response to Auxin Changes during Maturation-Related Loss of Adventitious Rooting Competence in Loblolly Pine (Pinus taeda) Stem Cuttings. Physiolgia Plantarum, 111, 373-380. http://dx.doi.org/10.1034/j.1399-3054.2001.1110315.x

[8] Swarup, R., Parry, G., Graham, N., Allen, T. and Bennet, M. (2002) Auxin Cross-Talk: Integration of Signaling Pathways to Control Plant Development. Plant Molecular Biology, 49, 411-426. http://dx.doi.org/10.1023/A:1015250929138

[9] Valdés, A.E., Fernández, B. and Centeno, M.L. (2004) Hormonal Changes through Maturation and Ageing of Pinus pinea. Plant Physiology and Biochemistry, 42, 335-340. http://dx.doi.org/10.1016/j.plaphy.2004.02.004

[10] Pop, T., Pamfil, D. and Bellini, C. (2011) Auxin Control in the Formation of Adventitious Roots. Notulae Botanicae Horti Agrobotanici Cluj-Napoca, 39, 307-316.

[11] Couée, I., Hummel, I., Sulmon, C., Gouesbet, G. and Amrani, A.E. (2004) Involvement of Polyamines in Root Development. Plant Cell Tissue and Organ Culture, 76, 1-10. http://dx.doi.org/10.1023/A:1025895731017

[12] Ragonezi, C., Klimaszewska, K., Rui-Castro, M., Lima, M., de Oliveira, P. and Zavattieri, M.A. (2010) Adventitious Rooting in Conifers: Influence of Physical and Chemical Factors. Trees, 24, 975-992. http://dx.doi.org/10.1007/s00468-010-0488-8

[13] Sánchez, C., Vielba, J., Ferro, E., Covelo, G., Solé, A., Abarca, D., De Mier, B. and Díaz-Sala, C. (2007) Two SCARECROW-LIKE Genes Are Induced in Response to Exogenous Auxin in Rooting-Competent Cuttings of Distantly Related Forest Species. Tree Physiology, 27, 1459-1470. http://dx.doi.org/10.1093/treephys/27.10.1459

[14] Konishi, M. and Sugiyama, M. (2006) A Novel Plant-Specific Family Gene, ROOT PRIMORDIUM DEFECTIVE 1, Is Required for the Maintenance of Active Cell Proliferation. Plant Physiology, 140, 591-602. http://dx.doi.org/10.1104/pp.105.074724

[15] Solé, A., Sánchez, C., Vielba, J., Valladares, S., Abarca, D. and Díaz-Sala, C. (2008) Characterization and Expression of a Pinus radiata Ortholog to Arabidopsis SHORT-ROOTGene. Tree Physiology, 28, 1629-1639. http://dx.doi.org/10.1093/treephys/28.11.1629

[16] Brinker, M., van Zyl, L., Liu, W., Craig, D., Sederoff, R., Clapham, D. and von Arnold, S. (2004) Microarray Analyses of Gene Expression during Adventitious Root Development in Pinus contorta. Plant Physiology, 135, 1526-1539. http://dx.doi.org/10.1104/pp.103.032235

[17] Jorrín, J., Maldonado, A. and Castillejo, A. (2007) Plant Proteome Analysis: A 2006 Update. Proteomics, 7, 2947-2962. http://dx.doi.org/10.1002/pmic.200700135

[18] Costa, P., Pioneau, C., Bauw, G., Dubos, C., Bahrmann, N., Kremer, A., Frigerio, J.M. and Plomion, C. (1999) Separation and Characterization of Needle and Xylem Maritime Pine Proteins. Electrophoresis, 20, 1098-1108.

http://dx.doi.org/10.1002/(SICI)1522-2683(19990101)20:4/5<1098::AID-ELPS1098>3.0.CO; $\underline{2-Z}$

[19] Gion, J.M., Lalanne, C., Le Provost, G., Ferry-Dumazet, H., Paiva, J., Chaumeil, P., Frigerio, 
J.M., Brach, J., Barré, A., de Daruvar, A., Claverol, S., Bonneu, M., Sommerer, N., Negroni, L. and Plomion, C. (1995) The Proteome of Maritime Pine Wood Forming Tissue. Proteomics, 5, 3731-3751. http://dx.doi.org/10.1002/pmic.200401197

[20] Mast, S., Peng, L., Jordan, T.W., Flint, H., Phillips, L., Donaldson, L., Strabala, T. and Wagner, A. (2010) Proteomic Analysis of Membrane Preparations from Developing Pinus radiata Compression Wood. Tree Physiology, 30, 1456-1468.

http://dx.doi.org/10.1093/treephys/tpq084

[21] Echevarría-Zomeño, S., Ariza, D., Jorge, I., Lenz, C., Del Campo, A., Jorrín, J. and Navarro, R. (2009) Changes in Protein Profile of Quecus Ilex Leaves in Response to Drought Stress and Recovery. Plant Physiology, 166, 233-245. http://dx.doi.org/10.1016/j.jplph.2008.05.008

[22] Blönder, C., Majcherczyk, A., Kües, U. and Polle, A. (2007) Early Drought-Induced Changes to the Needle Proteome of Norway Spruce. Tree Physiology, 27, 1423-1431. http://dx.doi.org/10.1093/treephys/27.10.1423

[23] Xiao, X., Yang, F., Zhang, S., Korpelainen, H. and Li, C. (2009) Physiological and Proteomic Responses of Two Contrasting Populus cathayana Populations to Drought Stress. Physiologia Plantarum, 136, 150-168. http://dx.doi.org/10.1111/j.1399-3054.2009.01222.x

[24] Sorin, C., Negroni, L., Balliau, T., Corti, H., Jacquemot, M.P., Davanture, M., Sandberg, G., Zivy, M. and Bellini, C. (1996) Proteomic Analysis of Different Mutant Genotypes of Arabidopsis Led to the Identification of 11 Proteins Correlating with Adventitious Root Development. Plant Physiology, 140, 349-364. http://dx.doi.org/10.1104/pp.105.067868

[25] Li, M. and Leung, D.W.M. (2000) Protein Changes Associated with Adventitious Root Formation in Hypocotyls of Pinus radiata. Biologia Plantarum, 44, 33-39. http://dx.doi.org/10.1023/A:1017910018880

[26] Chang, I.F., Chen, P.J., Shen, C.H., Hsieh, T.J., Huang, B.L., Kuo, C.I., Chen, H.A., Yeh, K.W. and Huang, L.C. (2010) Proteomic Profiling of Proteins Associated with the Rejuvenation of Sequoia sempervirens (D. Don) Endl. Proteome Science, 8, 64-80. http://dx.doi.org/10.1186/1477-5956-8-64

[27] Valledor, L., Jorrín, J., Rodríguez, J., Lenz, C., Meijón, M., Rodríguez, R. and Cañal, M.J. (2010) Combined Transcriptomic and Proteomic Analysis Identifies Differentially Expressed Pathways Associated to Pinus radiata Needle Maturation. Journal of Proteome Research, 9, 3954-3979. http://dx.doi.org/10.1021/pr1001669

[28] Chich, J., David, O., Villers, F. and Schaeffer, B. (2007) Statistics for Proteomics: Experimental Design and 2-DE Differential Analysis. Journal of Chromatography B, 849, 261-272. http://dx.doi.org/10.1016/j.jchromb.2006.09.033

[29] Kim, Y.K. and Yi, G.S. (2008) Sequential KNN Imputation Method. CRAN R Project, Version 1.0.1. http://cran.at.r-project.org/src/contrib/Archive/SeqKnn/

[30] Gonzalez, I., Le Cao, K.A., Monget, P., Coquery, J., Yao, F. and Liquet, B. (2012) MixOmics: Omics Data Integration. Project R, Package Version 4.0-1. http://CRAN.R-project.org/package=mixOmics

[31] Chong, I.G. and Jun, C.H. (2005) Performance of Some Variable Selection Methods When Multicollinearity Is Present. Chemometrics and Intelligent Laboratory Systems, 78, 103 112. http://dx.doi.org/10.1016/j.chemolab.2004.12.011

[32] Schevchenko, A., Wilm, M., Vorm, O. and Mann, M. (1996) Mass Spectrometric Sequencing 23 of Proteins Silver-Stained Polyacrilamide Gels. Analytical Chemistry, 68, 850-858. http://dx.doi.org/10.1021/ac950914h

[33] Diaz-Sala, C., Hutchinson, K. and Greenwood, M. (1996) Maturation-Related Loss in Rooting Competence by Loblolly Pine Stem Cuttings: The Role of Auxin Transport, Meta- 
bolism and Tissue Sensitivity. Physiologia Plantarum, 97, 481-490.

http://dx.doi.org/10.1111/j.1399-3054.1996.tb00507.x

[34] Browne, R., Davidson, C., Steeves, T. and Dunstan, D. (1997) Effects of Ortet Age on Adventitious Rooting of Jack Pine (Pinus banksiana) Long-Shoot Cuttings. Canadian Journal of Forest Research, 27, 91-96. http://dx.doi.org/10.1139/x96-160

[35] Wu, S.C., Györgyey, J. and Dudits, D. (1989) Polyadenylated H3 Histone Transcripts and H3 Histone Variants in Alfalfa. Nucleic Acid Research, 17, 3057-3063. http://dx.doi.org/10.1093/nar/17.8.3057

[36] Medford, J.I., Elmer, J.S. and Klee, H.J. (1991) Molecular Cloning and Characterization of Genes Expressed in Shoot Apical Meristems. Plant Cell, 3, 359-370. http://dx.doi.org/10.1105/tpc.3.4.359

[37] Atanassova, R., Chaubet, N. and Gigot, C. (1992) A 126 bp Fragment of Plant Histone Gene Promoter Confers Preferential Expression in Meristems of Transgenic Arabidopsis. Plant Journal, 2, 291-300.

[38] Horvath, D., Chao, W. and Anderson, J. (2002) Molecular Analysis of Signals Controlling Dormancy and Growth in Underground Adventitious Buds of Leafy Spurge (Euphorbia esula L.). Plant Physiology, 128, 1439-1446. http://dx.doi.org/10.1104/pp.010885

[39] Horvath, D., Schaffer, R., West, M. and Wisman, E. (2003) Arabidopsis Microarrays Identify Conserved and Differentially Expressed Genes Involved in Shoot Growth and Development from Distantly Related Plant Species. The Plant Journal, 34, 125-134. http://dx.doi.org/10.1046/j.1365-313X.2003.01706.x

[40] Galway, M.E., Heckman, J.W. and Schiefelbein, J.W. (1996) Growth and Ultrastructure of Arabidopsis Root Hairs: The RHD3 Mutation Alters Vacuole Enlargement and Tip Growth. Planta, 201, 209-218. http://dx.doi.org/10.1007/BF01007706

[41] Takeda, S., Gapper, C., Kaya, H., Bell, E., Kuchitsu, K. and Dolan, L. (2008) Local Positive Feedback Regulation Determines Cell Shape in Root Hairs. Science, 319, 1241-1243. http://dx.doi.org/10.1126/science.1152505

[42] Hu, Y., Zhong, R., Morrison, H. and Ye, Z.H. (2003) The Arabidopsis RHD3 Gene Is Required for Cell Biosynthesis and Actin Organization. Planta, 217, 912-921. http://dx.doi.org/10.1007/s00425-003-1067-7

[43] Jones, M.A., Raymond, M.J. and Smirnoff, N. (2006) Analysis of the Root Hair Morphogenesis Transcriptome Reveals the Molecular Identity of Six Genes with Roles in Root Hair Development in Arabidopsis. Plant Journal, 45, 83-100. http://dx.doi.org/10.1111/j.1365-313X.2005.02609.x

[44] Hayashi, S., Ishii, T., Matsunaga, T., Tominaga, R., Kuromori, T., Wada, T., Shinozaki, K. and Hirayama, T. (2008) The Glycerophosphoryl Diester Phosphodiesterase-Like Proteins SHV3 and Its Homologs Play Important Roles in Cell Wall Organization. Plant Cell Physiology, 49, 1522-1535. http://dx.doi.org/10.1093/pcp/pcn120

[45] Cheng, Y., Zhou, W., Sheery, N.I., Peters, C., Li, M., Wang, X. and Huang, J. (2011) Characterization of the Arabidopsis Glycerophosphodiester Phosphodiesterase (GDPD) Family Reveals a Role of the Plastid-Localized AtGDPD1 in Maintaining Cellular Phosphate Homeostasis under Phosphate Starvation. Plant Journal, 66, 781-795. http://dx.doi.org/10.1111/j.1365-313X.2011.04538.x

[46] Fotin, A., Cheng, Y., Grigorieff, N., Harrison, S.C., Kirchhausen, T. and Waltz, T. (2004) Molecular Model for a Complete Clathrin Lattice from Electron Cryomicroscopy. Nature, 432, 573-579. http://dx.doi.org/10.1038/nature03079

[47] McMahon, H.T. and Boucrot, E. (2011) Molecular Mechanism and Physiological Functions 
of Clathrin-Mediated Endocytosis. Nature Reviews Molecular Cell Biology, 12, 517-533. http://dx.doi.org/10.1038/nrm3151

[48] Xu, T., Wen, M., Nagawa, S., Fu, Y., Chen, J.G., Wu, M.J., Perrot-Rechenmann, C., Friml, J., Jones, A.M. and Yang, Z. (2010) Cell Surface- and Rho GTPase-Based Auxin Signaling Controls Cellular Interdigitation in Arabidopsis. Cell, 143, 99-110. http://dx.doi.org/10.1016/j.cell.2010.09.003

[49] Kitakura, S., Vanneste, S., Robert, S., Löfke, C., Teichmann, T., Tanaka, H. and Friml, J. (2011) Clathrin Mediates Endocytosis and Polar Distribution of PIN Auxin Transporters in Arabidopsis. Plant Cell, 23, 1920-1931. http://dx.doi.org/10.1105/tpc.111.083030

[50] Wang, C., Yan, X., Chan, Q., Jiang, N., Fu, W., Ma, B., Liu, J., Li, C., Bednarek, S. and Pan, J. (2013) Clathrin Light Chains Regulates Clathrin-Madiated Trafficking, Auxin Signaling, and Development in Arabidopsis. Plant Cell, 25, 499-516.

http://dx.doi.org/10.1105/tpc.112.108373

[51] Paciorek, T., Zazímalová, E., Ruthardt, N., Patrásek, J., Stierhof, Y.D., Kleine-Vehn, J., Morris, D.A., Emans, N., Júrgens, G., Geldner, N. and Friml, J. (2005) Auxin Inhibits Endocytosis and Promotes Its Own Efflux from Cells. Nature, 435, 1251-1256.

http://dx.doi.org/10.1038/nature03633

[52] Robert, S., Kleine-Vehn, J., Barbez, E., Sauer, M., Paciorek, T., Baster, P., Vanneste, S., Zhang, J., Simon, S., Covanová, M., Hayashi, K., Dhonukshe, P., Yang, Z., Bednarek S.Y., Jones, A.M., Luschnig, C., Anient, F., Zažímalová, E. and Friml, J. (2010) ABP1 Mediates Auxin Inhibition of Clathrin-Dependent Endocytosis in Arabidopsis. Cell, 143, 111-121. http://dx.doi.org/10.1016/j.cell.2010.09.027

[53] De Klerk, G.J., Krieken, W.V.D. and Jong, J. (1999) The Formation of Adventitious Roots: New Concepts, New Possibilities. In Vitro Cellular and Developmental Biology, 35, 189199. http://dx.doi.org/10.1007/s11627-999-0076-z

[54] Fogaça, C.M. and Fett-Neto, A. (2005) Role of Auxin and Its Modulators in the Adventitious Rooting of Eucalyptus Species Differing in Recalcitrance. Plant Growth Regulators, 45, 1-10. http://dx.doi.org/10.1007/s10725-004-6547-7

[55] Lee, H., Suh, S.-S., Park, E., Cho, E., Ahn, J.H., Kim, S.G., Lee, S., Kwon, Y.M. and Lee, I. (2000) The Acamous-Like 20 MADS Domain Protein Ifitegrates Floral Inductive Pathways in Arabidopsis. Genes and Development, 14, 2366-2376.

http://dx.doi.org/10.1101/gad.813600

[56] Pelaz, S., Ditta, G.S., Baumann, E., Wisman, E. and Yanofsky, E. (2000) B and C Floral Organs Identity Functions Requiere SEPALLATA MADS-Box Genes. Nature, 405, 200-203. http://dx.doi.org/10.1038/35012103

[57] Alvarez-Buylla, E.R., Liljegren, S.J., Pelaz, S., Gold, S.J., Burgeff, C., Ditta, G.S., Vergara-Silva, F. and Yanofsky, M.F. (2000) MADS-Box Gene Evolution beyond Flowers: Expression in Pollen, Endosperm, Guard Cells Roots and Trichomes. Plant Journal, 24, 457466. http://dx.doi.org/10.1046/j.1365-313x.2000.00891.x

[58] Rounsley, S.D., Ditta, G.S. and Yanofsky, M.F. (1997) Diverse Roles of MADS-Box Genes in Arabidopsis Development. Plant Cell, 7, 1259-1269. http://dx.doi.org/10.1105/tpc.7.8.1259

[59] Burgeff, C., Liljegren, S.J., Tapiz-López, R., Yanofsky, M.F. and Alvarez-Buylla, E. (2002) MADS-Box Gene Expression in Lateral Root Primordial, Meristems and Differentiated Tissues of Arabidopsis Thaliana Roots. Planta, 214, 365-372.

http://dx.doi.org/10.1007/s004250100637 